Мирослав Прокопијевић Институт за европске студије Београд
UDK: 316.334 .2

Прегледан научни рад Примљен: 31. 07. 2002.

\title{
SOCIAL CAPITAL DURING TRANSITION
}

Social capital matters, is the general message of this paper, and all those who ignore that, are going to fail either with their intellectual achievements or with their reform attempts. Part 1 explains why social capital was not an issue during communism, and why it arises during transition. Part 2 briefly addresses the concept of social capital; part 3 is about Pejovic's "interaction thesis". The enforcement of rules is discussed under 4, and the social capital on Balkans under 5.

\begin{abstract}
We simply have no good models of policies in Third World, transition or other economies.

D. C. North 2000, 8.

No one could overcome socialism as long as legal plunder continues to be the main business of the legislature.
\end{abstract}

F. Bastiat, The Law, 1850.

In many primitive societies there is no formal rule ordering people to be silent over some issues sensitive to their societies. ${ }^{1}$ Nevertheless, one just rarely can meet an individual from such a society to tackle open-mindedly some sensitive issue. What prevent people from discussing such issues are informal rules and norms, rather than formal ones. Say, a customary prohibition (taboo), to discuss some issue. In many European cities one has to pay for parking his car, and in addition, one has to pay a tip to local boys, that the car remains safe. Paying for the parking is a legal, formal obligation, while giving a tip to local boys or gang members what is sometimes called the racket - is an informal rule, a form of buying security

${ }^{1}$ This paper is worked out in 2002. during my stay at the ICER (International Centre for Economic Research), Turin, Italy. It would not emerge without the kind invitation by Prof. Roberto Toniatti, Trento University, to lecture his students from the Masters program about social capital during transition. The paper also served for the lecture "Re-constructing social capital in transition countries" at the Instituto Trentino di Cultura" in Trento, and induced a vivid discussion, from which I have profited a lot. Among others, who took part in this debate, I would like to mention those whose substantial criticism contributed to the quality of paper: prof. Roberto Toniatti, prof. Bruno Dallago, prof. Giorgio Fodor, Dr. Jens Woelk and Dr. Francesco Palermo from the Trento University, prof. Horst Brezinski, Freiberg University, Germany, prof. James Angresano, Albertson College of Idaho, USA. I am, naturally, alone responsible for the final product. 
Miroslav Prokopijević, Social Capital during Tranzition

for a car. In some countries, both expenditures are equally important and they both influence people's behavior.

\section{TRANSITION AND SOCIAL CAPITAL}

Transition in the post-communist countries encompasses some 27 states in Euro-Asia, with 380 million people inhabiting ca. 24 million square kilometers. People in transition countries are mutually so different: they speak officially some 25 languages, and a number of dialects, they belong to two races and to at least five larger religions, they mutually differ in their ethnic origin, habits and traditions. Some populations became familiar with what Max Weber has called "the work ethics", some have never experienced the work in a larger manufacturing or bureau firm; some live in nearly feudal system of local community, some are integrated in the "large society". Some communicate with the help of mass media and Internet, others are dominated by a tribal psychology. And some are cut off from the rest of the world and survive on extensive agriculture, while others enjoy the fruits of the information society.

So, the transition is a process, which does not happen in a vacuum. In all 27 or so cases, transition is related to specific societies, inheriting specific habits and customs. Informal rules have played a puzzling role during communism. On the one side, they were severely suppressed, while on the other side they have strongly contributed to the collapse of communism. Informal rules, like customs and traditions, come to play a larger role during transition, than they have played under previous, communist regime for an obvious reason. Communism has relied on a brutal enforcement of official, formal rules and a strong suppression of the informal ones. ${ }^{2}$ Seriously raised price for disregard of formal communist rules has indicated, people do not like these rules. A huge investment in monitoring and enforcing costs drastically raised the price of maintaining the (communist) game. ${ }^{3}$ High maintenance costs and lower productivity, taken in combination, have squeezed resources in communist countries, contributing strongly to their collapse. By raising the price for violation of formal rules, communist leaders intended to induce people's cooperation along formally designed lines. In some areas communist rulers enforced compliance, at least for so long until communism has lasted, while in others they failed to do so. People have stopped addressing others by using Mr. or Mrs. in daily conversation, and started to use "comrade" or "fellow"; the majority of people gave up their religious practices, although these practices have not completely

\footnotetext{
${ }^{2}$ Paldam feels that "dictatorship normally destroys social capital." (2000, p. 633) This drastic case is relatively rare, compared to different degrees of suppression.

${ }^{3}$ For example, the secret police of ex-GDR has employed permanently some 100.000 police force, and several hundred thousands of informal spies, which got rewards in temporarily honorariums, better business positions, or permits to travel abroad. This army has gathered some 6 million dossiers, in the population of ca.15 million people.
} 
Социолошки преглед, vol. XXXVI (2002), по. 3-4, стр. 255-273

disappeared. On the other hand, communist efforts to abolish marriage, as a bourgeois habit and institution, and to replace it with polygamy (polyandry) failed completely, although this also was a matter of new, revolutionary ideology. It seems that the acceptance of formal rules depends on two factors. First, in which relationship formal rules stay to informal ones? Second, if formal rules are to be accepted, what is at stake, and how this is important to individuals in question. Marriage is apparently more vital institution compared to addressing one with $\mathrm{Mr}$. or Mrs., and so it was able to survive and even suppress new communist legislation, in contrast to polite civic addressing, which has disappeared temporarily from public life.

But even in these areas where the communist legislation badly failed, ruling communists have arranged that there will be no reports about that. Nobody in the USSR after 1920 spoke about failed reform of marriage, nobody wrote about those who continued their religious practices, there was no reports in public media and books about prostitution or black market. If communists have failed in enforcing some rule, they arranged that there are no reports on that failure. By being measured just on its promises, communism seemed to be a harmonic, good society. Common people on the West cannot be blamed for accepting such views, if even some prominent intellectuals misjudged the situation so badly. "It is a vulgar mistake to think" - said Paul Samuelson in his Economics in 1981 - "that most people in Eastern Europe are miserable". ${ }^{4}$ That was said by a Nobel Prize winner just a few years before communism collapsed from itself in 1989.

When communism collapsed, the situation with formal and informal rules has been changed. Post-communist transition means a move from a communism to some kind of a more permissive regime. Transition consists - basically but not exclusively - in a threefold move: from dictatorship to democracy, from the rule of one party (man) to the rule of law, and from a planned to a market economy. ${ }^{5}$ "Basically but not exclusively means", that changes sweep all segments of life, i.e. they go beyond the three spheres mentioned above, but what happens in this three spheres merely determines the success of the transition. Transition implies the recognition of high transaction costs, borne by communists. By having no communism before, there would be no transition costs. Democracy, the rule of law and market economy reduce these costs. If people do not accept dictatorial decision and strange communist norms, what raises transaction costs, democracy will reduce them, by selecting acceptable decision makers in a society and by promoting prevailing norms via democratic channels. The rule of law will replace the rule of privileged communist elite; it will protect individual-, property- or minority-rights, and so it will contribute to a reduction in transaction costs. Finally, market economy will allow individuals to use more free resources over which they dispose;

${ }^{4}$ J. K. Galbraith even said: "The Soviet Economy has made great national progress in recent years". (New Yorker Magazine, 1984)

${ }^{5}$ Cf. my Transition, p. 4. See also North (2000), Pejovic (2000), Colombatto (2000). 
Miroslav Prokopijević, Social Capital during Tranzition

instead of pursuing imperatives of a central planning body, individuals are able to pursue their own interests, what again reduces transaction costs. Since transition reduces transaction costs, it can be considered as a cost-saving process. Costs are reduced to a different degree in different countries, and one can even measure the success of transition by measuring the reduction of these costs. ${ }^{6}$

What has been changed about social capital during transition? There are at least two changes worth mentioning. First, a move from dictatorship to democracy provides a more responsive environment for individual preferences to be counted. If socialist countries looked uniform at the time of communism, they widely diverge during transition what concerns preferences and habits dominating postcommunist societies. Secondly, in a strong opposition to the previous (communist) regime, where diversity or unintended consequences were strongly discouraged, larger political freedom after the collapse of communism made possible for diversity at least to appear and sometimes even to flourish. Diversity of preferences, unintended consequences and positive or negative aspects of life also got publicity. One can say, that transition has not just opened the way for informal rules into the public scene; moreover, it has promoted customs, traditions and local habits in the larger society.

\section{SOCIAL CAPITAL}

Before entering a substantial analysis of social capital during transition, let me try to outline the concept of social capital ${ }^{7}$ and some other concepts close to it. Capital is a stock that has value as a source of current and future flows of output and income. Capital stock is path dependent, since it indicates, people have saved and invested in the previous period, and therefore they have assets today. If human capital were the stock of skills and productive knowledge embodied in individuals, social capital ${ }^{8}$ would be the stock of informal rules embodied in individuals, which belong to a group, tribe or nation. By analogy, people have some social capital because they have invested that way. And precisely because of that, they have history. History is the past record on how people have invested in some period. In order to be accepted, habits and other social capital need to pass the test of time. Individual actors embrace norms that they view as requisite to their individual and collective well-being.

${ }^{6}$ There are some general projects to measure how good is some environment for doing business. Cf. The 2002 index of economic freedom. The Fraser Institute, Vancouver, provides another general index. "Transparency International" provides the country ranking based on the degree of corruption in different societies.

${ }^{7}$ For a review, see Woolcock, 1998.

${ }^{8}$ See, Dasgupta / Serageldin (Eds)(1999) on various definitions of social capital. They also pose interesting question on whether social capital can growth. For more about social capital, see 'Literature' at the end of this article. 
Социолошки преглед, vol. XXXVI (2002), по. 3-4, стр. 255-273

There are different definitions of social capital, and some of them are not correct for simply answering another question than asked. For example, Coleman (1988) defines social capital as people's ability to work voluntarily together. People work together even by inhabiting a completely different social capital. Another definition identifies social capital with social networks. (Putnam 1993) To the same family belongs the saying, "....social capital is defined as means which sustain cooperation between individuals by virtue of mutual inclusion in social network". Third definition identifies "social capital .../with/ the amount of benefits the individual can draw on his goodwill". ${ }^{10}$ It is true that social capital facilitates voluntary exchange, and this exchange is the result rather than proper content of social capital in a similar way in which 'social networks' are. If social capital is a network, all Sicilians in America should belong to the mafia, what for sure is not true. People may share the same social capital without belonging to the same network or group. It is also clear, that people adhere to inherited norms, because they expect this to be good for them, but again that is not a definition of social capital. It seems that social capital is the set of informal rules prevailing in the community or society. If so, it emerges the question, what is 'social' in the social capital? Social capital is apparently like glue in the community, something what does that members of a community do transactions among themselves rather than with foreigners. This glue is, however, always tied to individuals. Just individuals may embody social capital, in a similar way that just individuals - and not firms, organizations and states - may make decisions. 'Social' dimension is provided by the fact that a majority of individuals in a society shares some convention rather than by some imaginary entity that resides outside individuals, and they may take that in isolation. In order to be social, a norm should be dominant in a group, or at least, it should be accepted by a significant number of individuals in a group. Social norm needs to be sustained by their (dis)approval. Internalized norms are less dependent on the outside (dis)approval. It is clear that the 'social' outcome of the game is not to be obtained by counting and simply aggregating individual preferences, since, first, individual preferences mutually interact, and secondly, they are dynamic rather than static category. That is all what is the game theory about. Social capital, like all other rules, provides different incentives for action, and these incentives may results in either superior or inferior outcome concerning expected average or simple aggregate. ${ }^{11}$

From the fact that social capital has passed the test of time, it does not follow that it is a static category, although there are some speculations in Putnam and elsewhere that social capital needs centuries to develop. It is not just 'dynamic' be-

\footnotetext{
${ }^{9}$ Annen 2001, 320.

${ }^{10}$ Paldam 2000, p. 635. He points out, that "social capital deals with cooperation in groups and networks". (p. 631)

${ }^{11}$ Games like 'prisoner's dilemma', 'duel', 'land and see' provide illustrations for that. Cf. Luce \& Raiffa 1984.
} 
Miroslav Prokopijević, Social Capital during Tranzition

cause it emerges and disappears, or because it undergoes the changes; it possesses a dynamic structure even beyond that, since preferences of individuals do not exist independently from the knowledge and emotion crating process of exchange, which they are generating.

As a category influencing human behavior, social capital can be measured. Some ethnologic and anthropologic studies did first steps along that way, while the more precise methodology for measuring social capital is recent in origin. ${ }^{12}$

There is no certainty that selected rules are to be useful and fine. In a free world, individuals and groups are perfectly free to make their choices, but the choice is a chance for good or bad outcome. So, individuals and groups can select to do whatever they want, and they are perfectly entitled to do that, but in making any choice they cannot avoid to pay the cost of their choices.

It follows from the previous, that social capital is neither good nor bad per se, and that additional analysis on the case-by-case basis is needed, in order to decide about normative value of social capital. It is also up to additional analysis to find out how some social capital is supportive or disruptive for business. ${ }^{13}$ The rules and incentives are complicated and sometimes centuries pass before it becomes clear what are the consequences flowing from them. ${ }^{14}$ This applies both to formal and informal institutions.

Social capital is merely related to customs, beliefs, and traditions, expressed in informal rules, while formal rules are embedded in constitutions, laws, statuses and other official legislation. In some cases informal rules are implicit, in some others they are explicit. Sometimes informal rules are partly or completely integrated into formal ones, and sometimes they are in conflict with each other.

The fact that some rules are informal does not mean that they are inefficient. And the fact that some rule is formal, does not imply, it is efficient. Both types of rules enjoy different degree of acceptance, and both enjoy a very broad scale of enforcement. Internalized rules are less dependent on outside (dis)approval and enforcement.

${ }^{12}$ Fist systematic attempts did The World Bank (see about that in Dasgupta \& Serageldin 2000), and there are some proposals by other authors. Cf. Paldam 2000.

${ }^{13}$ Annen (2001) distinguishes between inclusive and exclusive social capital, where the former furthers economic performance, while the later does not.

${ }^{14}$ There is a legendary example of two Indian tribes in the North America, provided by Harold Demsetz, which were very similar to each other, except for one tribe has defined private property rights over forests and land, while the other has relied on common (tribal) property, over forests and land it has used. Land and forests have been carefully used and cultivated in the former example, while they were overexploited in the later example, due a permanent race among the tribe's members to use resources before others do that. Another consequence was, that the former tribe was stationary, while the later one has permanently changed its location, due to a permanent over-hunting, over-cutting trees and over-exploitation of the land, until it has eventually disappeared. 
Социолошки преглед, vol. XXXVI (2002), nо. 3-4, стр. 255-273

Laws and statutes emerge out of a legislative activity (a body entitled to do that), while informal rules and norms emerge gradually through repeated human interaction. Nobody can say who has invented some rule in a distant African tribe, in the same way in which nobody can say who has invented democracy, market economy or the rule of law. So, as a rule, we may know, who and when enacted some law, but we cannot know, who and when has accepted some habit. This produces an impression, that formal laws are purely artificial, what is not always the case, since some laws just codify existing informal norms, while informal rules are somehow natural. But, both natural and artificial norms may be strange and against the interests of some individuals, groups or even against the whole group (nation). Groups and societies practicising extremely strange norms would not survive and so neither would that norm in that group. Communist rules in the Central and Eastern Europe are just one example of disappearance of norms that were not accepted, what illustrates a previous statement, about the price to be paid for choosing some rules. The story on Indian tribes provides another example for how rules may be important. More frequent is the case that some norm is useful for some, and harmful for some other group. This gives rise to a competition among groups in effort to promote (prevent) the emergence of some law, what is well known in modern societies as rent-seeking. ${ }^{15}$

\section{FORMAL AND INFORMAL RULES}

Social capital affects all transactions, and is especially visible in opportunistic behavior, moral hazard, bargaining, monitoring and enforcing procedures. In other words, social capital is more visible there where discretionary power is employed. The same social capital will affect transactions into different ways under different circumstances. There, where uncertainty rules, people will have short time horizon, and they will prefer cash transactions, short term contracts, informal bargains and black market activity, over non-cash payments, long term contracts, formal deals and regular market. And the outcome of transactions will be different under different circumstances. Social capital is going to be exploited much more under uncertain circumstances, than under clear cut off conditions for doing business, and this is due to an active tendency of human being to take advantage of opportunity: "all available means" is easier to employ under uncertain, less restrictive circumstances. Good codification and good enforcement of rules outlaws some means, and so it reduces uncertainty and provides incentives for sound, cooperative strategies. Other elements that influence the use of social capital are the frequency with which transactions occur, specific conditions, disturbances to which they are exposed, and the extent to which they are supported by transaction-specific assets. Contrary to classical market transactions through the faceless or impersonal cont-

15 Rent-seeking is generally a looking for profit, beyond market, i.e. through the legislative activity. 
Miroslav Prokopijević, Social Capital during Tranzition

racting, out of which usual economics works, asset-specificity gives way to contracting in which the pairwise identity of the parties matters, what again points out the role of social capital. As Williamson and others have pointed out, there are several asset-specifics, like:

- quality specificity, when specific quality is required;

- time specificity, when transactions can happen just at some particular time;

- place selection (fixed, or related to successive sites);

- asset specificity, especially in component production;

- human capital specificity, emerging through learning by doing;

- customer specificity, i.e. products adjusted for a particular customer.

From experience and theory, it is well known that some types of social capital enhance some businesses, while the others do not. However, it is tricky question to draw a demarcation line and to establish a general case. Annen drives the distinction between inclusive and exclusive social capital, with the former enhancing cooperation, and the later discouraging cooperation. Social capital that creates open social networks has some advantages, since it fosters division of labor and stimulates specialization, fosters innovative knowledge and reduces rent seeking, while the exclusive social capital operates contrary to that (Annen 2001, p. 324-5). Based on two different types of social capital, co-operations prosper when go along openness and inclusion, concludes Annen, while the alternative one stagnate or even fail. There are some cases that would support such line of argument, but there are some others that would not. Mafia seems to be a very exclusive organization, but it is nevertheless up to the job. Like that, a limited number of Orthodox Jews has operated diamond industry for centuries; they were extremely successful, although very restrictive to newcomers in the field. And similar was about Medicci's bank. Its staff had some 50 agents, the owner trusted just 10 of them, and the bank nevertheless was extremely successful.

Prevailing social capital influences human actions in very different ways, like restricting choice, changing preferences or supporting preferences.

For example, restrictive norms narrow the scope of action. People grown up in a group dominated by communitarian values will be hesitant about privatization, people from risk averse families will at least prima facie ignore risky transactions, and they will opt for such actions just when all other options are exhausted. To too many tribal societies commercial habits sound pretty strange. To sum up, informal norms in some cases will avert (make impossible) some choices.

More frequently than they do restrict choice, informal rules do change preferences, in similar way in which people from different countries that are not native in English pronounce English words into different ways. Although the whole business is about profit, people from some cultures never mention it, and they behave in commercial transactions as they are about everything except for profit. By doing business in such an environment one has to be aware about prevailing preferences that change the ways of negotiation, bargaining and doing transaction. For examp- 
Социолошки преглед, vol. XXXVI (2002), по. 3-4, стр. 255-273

le, many from the West have experienced that the Oriental tradesman start with very high prices, and that there are just two ways to obtain a normal price: either to bargain ${ }^{96}$ patiently or to turn (seemingly, allegedly) your back (what is actually a threat of the exit option), and to wait for tradesman's reaction.

It is not always that social capital prevents or changes some choice. It can also facilitate some choice, providing additional enforcement for selected rules. This is the case merely there where formal and informal rules coincide.

Whether informal rules are going to restrict, change or facilitate some choice is basically arranged through the relationship of formal and informal rules. By following the research done by McAdams (1997), Steve Pejović (1999, p. 5-6) codifies above deliberations by envisaging the four relationships between formal and informal institutions.

1) Formal institutions can suppress, but they cannot change informal institutions. Restrictions on smoking have suppressed, but failed to exhaust this habit. A similar legal ban on dueling was more successful, since dueling was already outdated at the end of XIX century, while smoking apparently is still not.

2) Formal rules are in direct conflict with informal rules. Pejovic remarks, that the difference between formal rules suppressing informal rules and being in conflict is merely one of degree. The prohibitions of liqueurs in the U.S. in 1930s and in Russia in 1980s provide the illustrations for this case. Both formal regulations failed in face of a strong habit of drinking alcohols, and both - quite predictably - strengthened mafia, since this organization offered illegally what people wanted to get, and its prominent members became rich. No other single move have strengthened mafia more in these two countries than the ban on alcohol. ${ }^{17}$

3) Formal rules are either ignored or rendered neutral. People sometimes ignore legal rules and settle their arrangements by using informal norms, which they consider for more efficient. In some countries people use traditional methods to solve their disputes, in a similar way in which firms from some American industries use their own activity-specific provisions for regulation of exchange.

4) Formal and informal rules cooperate. Examples for such cases include the protection of individual reputation, the protection of private property, "drive right, drive left" rule, etc. This happens in cases where individual and

\footnotetext{
${ }^{16}$ In any case it remains the impression, that bargaining is more for personal amusement than for business purposes, and that its presence merely reflects a habit, of having fun while doing business.

${ }^{17}$ It is interesting to point out, that in both cases left-wingers were the most enthusiastic for banning alcohol, but also very enthusiastic in blaming mafia for being rich and more powerful, although it was clear in advance, that this is going to be the outcome.
} 
Miroslav Prokopijević, Social Capital during Tranzition

social interests coincide, ${ }^{18}$ and for that reason it is easy to monitor and enforce the rules of the game depicted under 4).

On the basis of previous analysis, Pejović suggests the interaction thesis: "If changes in formal rules are in harmony with the prevailing informal rules, the interaction of their incentives will tend to reduce transaction costs in the community (that is, the cost of making an exchange and the cost of maintaining and protecting the institutional structure) and clear up resources for the production of wealth. When new formal rules conflict with the prevailing informal rules, the interaction of their incentives will tend to raise transaction costs and reduce the production of wealth in the community" $(1999, \mathrm{p}$. 7). In order for a market economy to thrive, implementing the necessary external institutions might not suffice if they are not supported by internal institutions compatible with them. ${ }^{19}$ As Pejović rightly points out, various observations support this conviction. Some examples are already mentioned, with transition being no exception. The most successful transition countries are those, where, like in Estonia, Czech Republic or Hungary, private economy dominated some decades ago, i.e. before communists took the power, and where it existed the "work ethics". Other countries like Moldova, Bulgaria or Macedonia cannot simply repeat this model, since history and social capital there are different. If history and social capital matter during transition, the best way for some country would be to enforce just those rules where informal and formal norms coincide, restricted for principles of the rule of law, and to let people work and find out optimal solutions, which than may be codified ex post. Otherwise, i.e. by imposing the rules and programs, countries risk a sharp conflict between formal and informal institutions, and the outcome could be just an economic and social disaster.

\section{THE ENFORCEMENT OF RULES}

A badly mistake one may commit is to say, that all post-communist countries have to follow the same pattern of development. This would be impossible even if these people would agree to accept such an unitary reform pattern. Their eventual willingness to change the path of development may be in a sharp conflict with rules and devices they actually use. The outcome will be similar to what happened in Latin America, where many populations and their elites have accepted principles of the U.S. constitution. Nevertheless, the application and partial enforcement of these

\footnotetext{
${ }^{18}$ The cooperation of formal and informal rules is necessary but not sufficient condition for some rule's plausibility. Burning widows in India or killing people over 65 in Japan in $19^{\text {th }}$ century and earlier, might easily be accepted both as formal and inform rule among these population at that time. A country having such formal rules cannot became the rule of law, until cruel and unusual practices are outlawed.

${ }^{19}$ The interaction thesis in its weaker form is supported by a number of economists, like Buchanan, Arrow or North.
} 
Социолошки преглед, vol. XXXVI (2002), по. 3-4, стр. 255-273

(same) principles gave a completely different outcome in the U.S. and throughout the Latin American world. ${ }^{20}$ The explanation is straightforward, and it is based on two reasons. First, it is true that the Latin American countries have copied the U.S. constitution and laws, but this holds merely for their positive provisos granting rights to individuals. Latin American countries stopped short of copying the negative provisos of the U.S. Constitution, which specify what is not permitted for the state to do. These provisos are essential in restraining the power of the state, including its officials and agencies, and they make sure that nobody is above the law. If these provisos are not sufficiently developed or if they are missing in a constitution, there is nothing to stop those in charge from violating individual, property, minority or other rights. For that reason uncertainty rules, and this raises transaction costs. Secondly, the principles of the U. S. Constitution and laws have grown up from some type of informal rules, which are characteristic for the AngloAmerican world; these principles are not at home in Latin America, where other habits and traditions prevail. The effort to implant seeds of one culture into completely different one, must fail, since the new implants may contradict to the informal rules that prevail there. So the provisions of the U.S. Constitution have remained a dead letter on paper in Latin America, and practices have been driven by usual, homegrown informal rules. This has raised transaction cost, i.e. the costs of maintaining the social game. Formal rules require one type of behavior, while the informal rules require something else. To have higher transaction costs would mean, that some resources have to be squandered, mis-invested. Despite this investment effort - which appeared to be a waste of resources - the economic game remained uncertain. This has reduced the output, and so the growth rates of the Latin American countries have remained far behind of that in the United States. From 1870 to 1990 the United States have grown on average rate of $1.75 \%$. By having a growth rate during the same period of just one (1) percentage point lower than they had, the U.S. would today be at the development level of Mexico, which has now 9 times lower average income than the U.S. do have. ${ }^{21}$ The only way to make sure that some rules work in an environment is to provide individuals with incentives to accept them. This may happen either due to a flow of benefits for

${ }^{20}$ Douglas C. North (1990, p. 101), a Nobel Prize winner for economics, observes: "Many Latin American countries adopted the U.S. Constitution (with some modifications) in the nineteenth century, and many of the property rights laws of successful Western countries have been adopted by Third World countries. The results, however, are not similar to those in either the United States or other successful Western countries. Although the rules are the same, the enforcement mechanism, the way enforcement occurs, the norms of behavior, and the subjective models of the actors are not /the same/".

${ }^{21}$ Cf. R. Barro \& Sala-y-Martin, X. (1995), p. 1: “...if the growth rate had been lower by just 1 percentage point per year, than the U.S. real per capita GDP in 1990 would have been close to that in Mexico and Hungary, and would have been about \$ 1000 less than that in Portugal and Greece". These authors also state, that the U.S income grew by a factor 8.1 from $\$$ 2244 in 1870 to $\$ 18258$ in 1990 , all measured in 1985 dollars. This corresponds to average growth rate of $1.75 \%$ during 120 years in question.. 
Miroslav Prokopijević, Social Capital during Tranzition

individuals or due some force, backing up the rules. But, obedience based just on power will work badly and last shortly.

Not only that different transition countries have different cultural heritage. They also have different macroeconomic situation, different geography, different stock of economic knowledge, and different ability to adjust to economic advices.

We all know that a private market economy is much efficient than the state owned one, and this insight is confirmed for many times in different and mutually independent researches. ${ }^{22}$ However, if there is a social norm or broad social feeling against private property, and educational systems under socialism have broadened such sentiments, quick and efficient privatization is next to impossible, since the former mentioned stance will be an obstacle both for privatization and reform. This outcome will change nothing on our conviction about advantages of private over state owned economy, but this conviction alone is not able to change the country in question. Political arrangements sometimes change people's moral. The whole system under communism, including education and propaganda, has worked against values on which the constitutional market democracy is based upon. Communist standards provide very bad background for legal and pro-market reforms, and the problems are even larger there, where communist heritage operates in conjunction with backwardness and with social capital, which is restrictive toward reforms. Communist governments have suppressed or changed social capital, but it has not disappeared completely. It is not true that the whole social capital during communism was evaporated or destroyed, and that just connections among people on some positions were tolerated. It also seems unlikely that efforts to rebuild social capital took a wrong way into development of malign (criminal) ${ }^{23}$ instead of benign social capital, which enhances cooperation and entrepreneurship. Larger criminal activity in successful transition countries took part just for a while, shortly after communism collapsed; but larger criminal activity is characteristic for less successful transition countries, which as a rule also run large black market activity.

Members of general community enforce social capital embodied in social norms, provided the community members have internalized the norms. If this is not the case, social enforcement is needed. Nevertheless, private enforcement is much efficient, although it happens rare. In other words, rules and norms are privately enforced or selfenforcing, just if the gain from their adherence is larger than the loss in the case of their violation. So, for example, some main traffic rules are selfenforcing. If one violates the basic traffic rules (drive left-drive right, do not go through the red light, etc.), he/she is going to bear very high costs. Some other traffic rules, like the speed limit, are however not selfenforcing, and as the consequence, a number of policemen is needed to enforce a reasonable level of compliance with such rules. Connections have played a significant role, but they are visible nearly everywhere, in Latin America or Italy - where there was no commu-

${ }^{22}$ Cf. Megginson \& Netter 2001, pp. 322-5.

${ }^{23}$ Cf. Paldam 2000, p. 635. 
Сочиолошки преглед, vol. XXXVI (2002), nо. 3-4, стр. 255-273

nism, and criminal activity is not significantly larger in Hungary or Czech Republic than in members of the European Union from South Europe. These troubles may be caused by some other factor.

Post-communist (transition) countries do not have a good historical record regarding what the rule of law means. Some elements of the "Rechtsstaat", a younger and less developed cousin of the rule of law, which existed in some countries where communists took power, were definitely wiped out under communist rule. Communists naturally had some legal system, but it was envisaged to promote the power of the state and bureaucrats rather than to restrain them. As such, it was merely a travesty of justice. In such an environment it would be unrealistic to expect that the rule of law may emerge quickly and successfully. For keeping elementary order one does not need to wait until the rule of law is fully developed.

Having in mind that the idea of the rule of law was born out of a very long evolution of the Anglo-Saxon common law, merchant law, tort law, etc., one can imagine the difficulty in transferring it into a rather different environment, such as that of post-communist countries. The customs, habits and social capital of the people in post-communist countries are different from those in the U.S. or United Kingdom, so that imports would be unlikely to work if not adjusted, like in Sweden, Spain or Switzerland, where the rule of law is mixed with the law produced by the state and with local customs. Even if the rule of law would be somehow confirmed by parliaments, it is questionable to what degree people would respect such rules. Observed regularities show that people tend to respect those formal rules that are in accordance with their informal rules and habits, and to ignore those formal rules that do not accord - as the interaction thesis suggests. If people violate formal rules just occasionally, it is easy to enforce the law. But if violation becomes the rule, or if people simply ignore the rules, the majority cannot be imprisoned. Rules that people ignore or violate routinely must be adjusted, changed, or even replaced. Even enforcement mechanisms must be adjusted to habits and informal rules prevailing in the population. It is important to keep in mind that nowhere are rules completely respected and completely enforced. If significant differences exist even among developed countries, why they should not exist among the transition countries.

The importance of social capital and informal rules is so obvious, that are rare the authors who believe, all law and its enforcement stem exclusively from the government. This is not the case even if one assumes, that there are people and countries without any social capital. Even in a state without social capital, and of entirely state law, assuming something like that for the sake of thought experiment, individuals may use different strategies (depending on the game) to influence the other side - like using exit option or a threat to defect. The idea of exclusively state enforcement is surprising in the light of the fact, that in nearly all countries besides some uniform commercial code, which defines a comprehensive set of contract default rules - it exists also private commercial law. That is an activity- 
Miroslav Prokopijević, Social Capital during Tranzition

specific set of default rules, that are created by firms and their private associations (chambers of commerce), and that are enforced in associations' arbitration tribunals. In the U.S. there are more than 50 private commercial laws, including diamond, cotton, rice, peanuts or grain industries. In some fields, the acceptance of the specific code is a condition for association's membership, what is frequently a precondition for doing specific business. Finally, that is not the only example of privately enforced rules, as the case of some traffic rules shows. Anyway, it is not good to conceptualize informal settlements (private ordering) according to the model of the system of government courts. ${ }^{24}$

There is no analogy, whatsoever, between transition and privatization rules, on the one side, and the main traffic rules, on the other side. Both transition and privatization have their losers and their gainers. And both groups, although they may be on non-equal terms, have an interest to get what they want. So, transition and privatization cannot simply happen or flow from themselves, like a traffic flow on some highway; they can be implemented just by using the enforcing mechanisms of the state. Any discretionary action of the state means, that there is several different options, and that somebody has to decide, which option is to be adopted and enforced.

\section{SOCIAL CAPITAL ON BALKANS}

Similar to other parts of Europe, like Scandinavia, Iberian peninsula, Germanspeaking countries or Benelux, the Balkans have their own social capital. Some even say that Balkans produces so much history, that it cannot be consumed domestically. By having a dramatic history of divisions and conflicts, foreign occupation and wars, the Balkan countries have remained small, mistrusted and underdeveloped. ${ }^{25}$ Political and other uncertainties prevented a stronger economic development, and underdevelopment again fueled uncertainties, creating a fatal circle: uncertainty-poor development-uncertainty. Capital accumulates over long periods of time where it gets effective protection, and this is missing on the Balkans. Even though democracy has taken root on the Balkans, the rule of law is largely absent. Predictably, economic growth has been episodic.

By being small and involved in frequent conflicts, the Balkan countries developed mistrust into the prevailing philosophy. Long Turkish occupation, German attacks during world wars and the Soviet threat after the II WW have strongly contributed to the perception of the outside world as inimical. Larger powers provided continuity to such a perception by instrumentalizing the Balkan countries for their own purposes during peacetime. Economic inefficiency of the Balkan coun-

\footnotetext{
${ }^{24}$ Williamson, O. E. (1983)

${ }^{25}$ Balkanization became synonymous with conflict, confrontation and division along ethnic, religious and other lines.
} 
Сочиолошки преглед, vol. XXXVI (2002), no. 3-4, стр. 255-273

tries completed the picture of small isolated states nearly cut off from the rest of Europe.

With a few exceptions and that also for a short period of time,${ }^{26}$ the Balkan countries were never democracies until 1990s. Instead of the rule of law, the Balkan countries (after liberation from Turkey in the midst of XIX century) were dominated by the state law, which merely was a tinny copy of the Austrian legislation. Except for Slovenia and Hungary, Balkans remained largely non-industrialized until the second part of XX century. Slovenia and Greece are today the most developed, while Albania, Bosnia and Macedonia are the least developed among the Balkan countries.

External threat in conjunction with internal poverty have promoted the state into agency that has to guarantee for security of all their citizens. State is perceived as a mother that has to take care about her children (citizens) "from the cradle to the grave". Unlike the U.S. or West Europe, the founders of the Balkan countries seem to have been enticed by their local social ethos to ignore the dilemmas they would create by laying down in the legislation the commitment for society (state) to provide security from economic and other risks to all their members. Although such a commitment has grown out of social capital, staged by historical threats, economic underdevelopment and local poverty, it cannot in practice be easily aligned with robust individual freedom, personal responsibility and economic efficiency. More or less, people in all Balkan nations value security more than freedom, and rank distributive justice over allocative efficiency. Efforts to create social security under conditions of poverty provide incentives for rent-seeking on the one side, and favor demagogues and predators among politicians, on the other side, what leads to a redistribution of poverty and preservation of stagnant economy. Yet, in practice and with flow of time, interest groups have learned (improved methods) to exploit the social capital and provisos based on it. When politicians promise to deliver "justice", "social and economic equality" or "decent standard of living", they actually take into account that state activity is not properly constrained, and that they are able to redistribute wealth from one group to another; what should be called a classical theft, as Bastiat mentioned in the fragment at the beginning of this text, becomes an active and just government policy. Instead to deliver promises, this policy merely increases corruption, rent seeking and instability, and induces larger promises and state intervention in the next round. Soviet socialism has collapsed throughout the Central and East Europe, but the seeds of socialism have survive, and it may happen that in the next round socialism is going to be introduced in a completely democratic way. Those who do not want to take part into this game on the Balkans were able to opt from resignation to emigration.

Emigration from the Balkan countries was very intensive from early XIX century to now, and in some periods it took form of mass emigration to the U.S.,

${ }^{26}$ Greece was a democracy late in XIX century, and afterwards in 1953-66 and from 1974 on; Serbia was democracy in the period 1881-1914. 
Miroslav Prokopijević, Social Capital during Tranzition

Western Europe and Australia. Through emigration, the Balkan countries have lost their most productive, the most risk taking and the most innovative population. This increased the relative participation of mediocre and poor citizens throughout the region. Poor people are also rent-seekers, which fuel socialist habits and induce communist in power. Despite many elections held throughout 1990s, communist rulers were in power nearly all the time from the collapse of communism to now, especially in Romania, Albania, Macedonia and FR Yugoslavia. If the opening of markets suggests that more of the types of goods currently produced by relatively unskilled members of the domestic labor force will be imported, political coalitions organized in opposition to market extension will find support among unions and their political representatives.

The concept of state as a mother that takes care about children is neither good for legal stabilization nor for economy and democracy. The law undergoes a transformation in such circumstances: instead to protect individuals from the encroachment of government power, it becomes the power that enables the government to lord over the people. Instead to protect people by constraining the state, the law becomes the instrument that enhances the power of the state. This enlarges the power of rulers, which are required to introduce even more socialist's policies, even if they prima facie did not intended to do so. Similar is with democracy. Instead to be "a rule of people, by the people and for the people", democracy degenerates into rigid rule of the majority, and sometimes even into the tyranny of majority. Politicians elected on this wave of popular support tend to blame constitution and laws for bounding their hands in an open search for more power; when they get it, they suspend or ignore law and institutions, communicate directly with masses (in an allegedly effort to address their needs), speed up re-distributive policies, and undermine the economic basis of the society. Such an environment is not perceived to be good for minorities, and it actually becomes a driving force fueling independence movements among minorities. ${ }^{27}$ When one group decides to secede from the mother country, this increases the pressure on other groups to follow the suit. Ethnically or religiously homogenous majorities respond to secessionist tendencies with centralization, what additionally exercises the pressure to minorities. And this becomes a systematic generator for creating always smaller ethnically homogenous states. In order to be able to survive small states are directed to outside help. Since there is no free lunch, larger powers condition the eventual assistance with some concessions to their interests. This systematically induces larger powers to the Balkans, and results in a conflict among them on the narrow Balkan land, what again explains, why one world war started there, together with a number of local wars.

Other policies are needed to avoid, that perpetuation of bad conditions is promoted into second human nature, i.e. into a conviction, that there is no escape

${ }^{27}$ It actually depends on which logic prevails - integrative or disintegrative. About integrative approach, see Woelk 2001. For the case of secession, see: Prokopijević 1995. 
Социолошки преглед, vol. XXXVI (2002), по. 3-4, стр. 255-273

from that bad state of affairs. The majority of the Balkan countries either are not able to find an exit from this situation on their own, or this is going to be a very time consuming process. Foreign powers cannot simply implement and stabilize the rule of law, market economy and democracy, like the U.S. has restored them in the West Europe after the IIWW. It was easy to restore them in the West Europe, since they have existed before the IIWW, and it is impossible to implement them quickly on the Balkans, since they have nearly never existed there. This speaks against another Marshall Plan for the Balkans, in analogy to the West Europe. What is to be done in such a desperate situation, where imports do not work and domestic seeds of market democracy under the rule of law are too weak? Probably a combination of domestic effort and foreign incentives may be helpful. The end of the Cold War and collapse of communism stage the scene for such an effort. Larger powers and international community may encourage the Balkan countries - via "stick and carrot" policy - to improve democracy and their legal systems, or to create a better environment for private investment rather than to let them wait on donations, which have little effect on real condition, and which are merely squandered through bad state investment or corruption. A free trade zone to be introduced in 2004 among all Balkan countries is a way to increase productivity through specialization. Further improvements in the rule of law are quite essential both for encouraging trade and for reducing incentives for socialist demagogues and rent seekers. Concentration of productive effort on one good followed by exchange for other goods becomes a means of getting more of all goods than can possibly be attained in autarky. And starting to change autarky will be equivalent to starting to change the prevailing social capital, i.e. those elements in social capital which prevent mutually profitable exchange and development on the Balkans.

\section{LITERATURE}

Annen, K. (2001) Inclusive and exclusive social capital in the small-firm sector in developing countries, Journal of institutional and theoretical economics (JITE), vol. 157, 2, pp. 319-330.

Arrow, J. K. (1974) Limits of organization, N. York: W. W. Norton.

Arrow, J. K. (2000) Economic transition: speed and scope, Journal of institutional and theoretical economics, vol. 156, 1, pp. 9-19.

Barro, R. J. / Sala-i-Martin, X. (1995) Economic growth, N. York: McGraw-Hill.

Becker, G. S. / Murphy, K. M. (2000) Social economics: market behavior in a social environment, Cambridge \& London: Harvard UP.

Buchanan, J. (1997) Post-socialist political economy, Cheltenham \& Lyme: E. Elgar.

Coleman, J. S. (1988) Social capital in creation of human capital, American journal of sociology, vol. 94, pp. 95-120. Reprinted in Dasgupta \& Serageldin (Eds) (1999).

Colombatto, E. (2000) On the concept of transition, Torino: ICER.

Dasgupta, P. / Serageldin, I. (Eds)(2000) Social capital: a multifaceted perspective, Washington: The World Bank. 
Miroslav Prokopijević, Social Capital during Tranzition

Deth, J. W. V. a. o. (1999) Social capital and European democracy, London: Routledge.

Gambetta, D. (Ed)(1988) Trust: making and breaking cooperative relations, Oxford: Blackwell.

Gambetta, D (1988) Mafia: the price of distrust, in: Gambetta, D. (Ed) (1988).

Hirschman, A. (1982) Rival interpretations of market society: civilizing destructive, or feeble?, Journal of economic literature, vol. 20, pp. 1463-84.

Klein, B. (1980) Transaction cost determinants of 'unfair' contractual relations, American Economic Review Proceedings, vol. 70, pp. 356-62.

Luce, D. \& Raiffa, H. (1984) Games and decisions, N. York: Dover.

Macaulay, S. (1963) Non-contractual relations in business, American sociological review, vol. 28, pp. 55-70.

McAdams, R. (1997) The origin, development, and regulation of norms, Michigan Law Review, vol. 96.

Megginson, W. L. \& Netter, J. M. (2001) From state to market. A survey of empirical studies on privatization, Journal of economic literature, vol. 39, 2, pp. 321-389.

North, D. C. (1990) Institutions, institutional change and economic performance, Cambridge: Cambridge UP.

North, D. C. (2000) Big-bang transformations of economic systems: An introductory note, Journal of institutional and theoretical economics, vol. 156, 1, pp. 3-8.

Paldam, M. (2000) Social capital: one or many? Definition and measurement, Journal of economic surveys, vol. 14, 5, pp. 629-653.

Pejović, S. (1999) The effects of the interaction of formal and informal institutions on social stability and economic development, Mimeo, (published in the Journal of market and morality).

Pejović, S. (2000) After socialism: where hope for individual liberty lies?, Torino: ICER working papers (www.icer.it)

Polinsky, A. M. / Shavell, S. (2000) The economic theory of public enforcement of law, Journal of economic literature, vol. 38, 1, pp. 45-76.

Prokopijević, M. (1995) Secession: what matters?, in: Troper, M. \& Karlsson, M. (Eds) Law, justice and the state II, Stuttgart: Steiner, pp. 122-132.

Prokopijević, M. (2001) Transition, Torino: ICER. Also available at: www.icer.it , paper No. $15 / 01$.

Putnam, R. D. (1993) Making Democracy Work: Civic Traditions in Modern Italy, Princeton: Princeton UP.

Reisman, D. (1999) Conservative capitalism: the social economy, N. York: St. Martin Press \& London: Macmillan.

The 2002 index of economic freedom, Washington, D.C.: The Heritage foundation \& The Wall Street Journal. Also available at: www.heritage.org

Ullmann-Margalit, E. (1977) The emergence of norms, Oxford: Clarendon.

Williamson, O. E. (1983) Credible commitments: using hostages to support exchange, American Economic Review, vol. 73, pp. 519-540.

Woelk, J. (2001) Südtirol: ein Lehrbeispiel für Konfliktlösung, Die Friedens-Warte, 1, pp. 101-124.

Woolcock, M. (1998) Social capital and economic development: toward a theoretical synthesis and policy framework, Theory and Society, vol. 27, pp. 151-208. 
Мирослав Прокопијевић

Резиме Институт за европске студије

Београд

\section{ДРУШТВЕНИ КАПИТАЛ У ТРАНЗИЦИЈИ}

Социјални капитал у смислу скупа преовлађујућих неформалних норми међу становништвом неке земље има снажан утицај и на ток транзиције. Део 1 расправља о томе зашто социјални капитал није био тема током комунизма, а део 2 о појму социјалног капитала. Део 3 је посвећен «интерактивној тези» професора Пејовића. Спровођењу правила је посевећен 4. део, а социјалном капиталу на Балкану 5. део.

Кључне речи: друштвени капитал, транзиција, економија. 